\title{
Rethinking Spirituality through Music Education in Istanbul
}

\section{Banu Şenay}

\section{(2) OpenEdition \\ 1 Journals}

\section{Electronic version}

URL: http://journals.openedition.org/ejts/5539

DOI: $10.4000 /$ ejts.5539

ISSN: $1773-0546$

Publisher

EJTS

\section{Electronic reference}

Banu Şenay, «Rethinking Spirituality through Music Education in Istanbul », European Journal of

Turkish Studies [Online], 25 | 2017, Online since 08 December 2017, connection on 21 December 2020. URL : http://journals.openedition.org/ejts/5539; DOI : https://doi.org/10.4000/ejts.5539

This text was automatically generated on 21 December 2020.

(C) Some rights reserved / Creative Commons license 


\title{
Rethinking Spirituality through Music Education in Istanbul
}

\author{
Banu Şenay
}

Research for this study was supported by the Orient Institute in Istanbul and by the MacArthur Fellowship of the University of Melbourne. I would like to thank Dr Alexandre Toumarkine for fieldwork support and EJTS's anonymous reviewers for their helpful comments.

\section{Introduction}

The ney, an end-blown reed flute, and the key wind instrument of Ottoman classical music, has experienced a major revival over the last ten years, both globally and in Turkey. Its immense popularity is confirmed not only by the huge growth in ney music both live and recorded, but also by a growing demand for ney-learning and lessons in Turkey's urban centres. Willing students, mostly adults, take lessons in a plethora of new pedagogical sites ranging from private ney studios to cultural and religious organizations, from university clubs to local müfti offices functioning under the Turkish State's supersized bureaucratic institution, the Directorate of Religious Affairs (Diyanet Işleri Başkanlı̆̆ı). Ney lessons are fully subscribed to in hundreds of adult education centres sponsored by metropolitan and local councils in major cities. "The ney is going through its golden age" proclaimed neyzen [ney player] Aziz ş. Filiz in a 2011 interview, commenting upon "its changing meanings" in this remarkable new episode in the instrument's social life.

Although the constituencies of ney learners are as diverse as its teaching sites, "a quest for spirituality (maneviyat ${ }^{3}$ )" is often pronounced as one key motive in this popular recreation of ney-learning. But is this really the case? And what might be meant by spirituality anyway? It is now a well-established critique in the social sciences that "sp irituality" is a "vague" (Van der Veer 2009: 1107), "floating" (Cobussen 2008: 25) and far 
too all-embracing term. As Anna King writes, the word carries diverse and even contradictory meanings, encompassing for example

an approach to God, a religious practice, a devotional path, a discipline, a creative energy, a sense of awe and mystery, a distinctive religious ethos or mode of experience, an inner moral orientation, the ethical transcendence of self, mystical awareness, the sense of the numinous, an appreciation of the mysteries and depth of human experience (1996: 343).

This diversity is expressed, too, in the variations of "spiritual" talk surrounding the ney. For example, for some ney players, the ney is hailed as an "instrument of the soul", supposedly endowed with a natural ability to express the inner voice of the individual. ${ }^{4}$ The material form of the instrument serves as the primary proof for this metaphoric association. Given its reed structure, the ney is celebrated for being "simple", "natural" and "pure", qualities which make it appear as a means for achieving wholeness and inner transformation. For more Islam-inclined students, the ney's intrinsic spirituality is revealed in its thin, vertical shape, melded with alif, the first letter of the Arabic alphabet with its symbolic reference to oneness of God. Here ney playing, unlike, say, piano music, constitutes an activity conducive to deeper piety. Its sound is said "to arouse a desire to worship," and "to draw oneself closer to God," as one learner described her own spiritual experience of playing (Interview, 26 May 2013). Similarly, the world music artist Omar Faruk Tekbilek claims that "the ney plays the breath of God" (Bessman 2002), assigning a spiritual meaning to the very act of "blowing" ( üflemek). ${ }^{5}$ For Tekbilek, what makes ney-playing an experience of "blessing" is its "generating of awareness of one's breath" (Dede 2003).

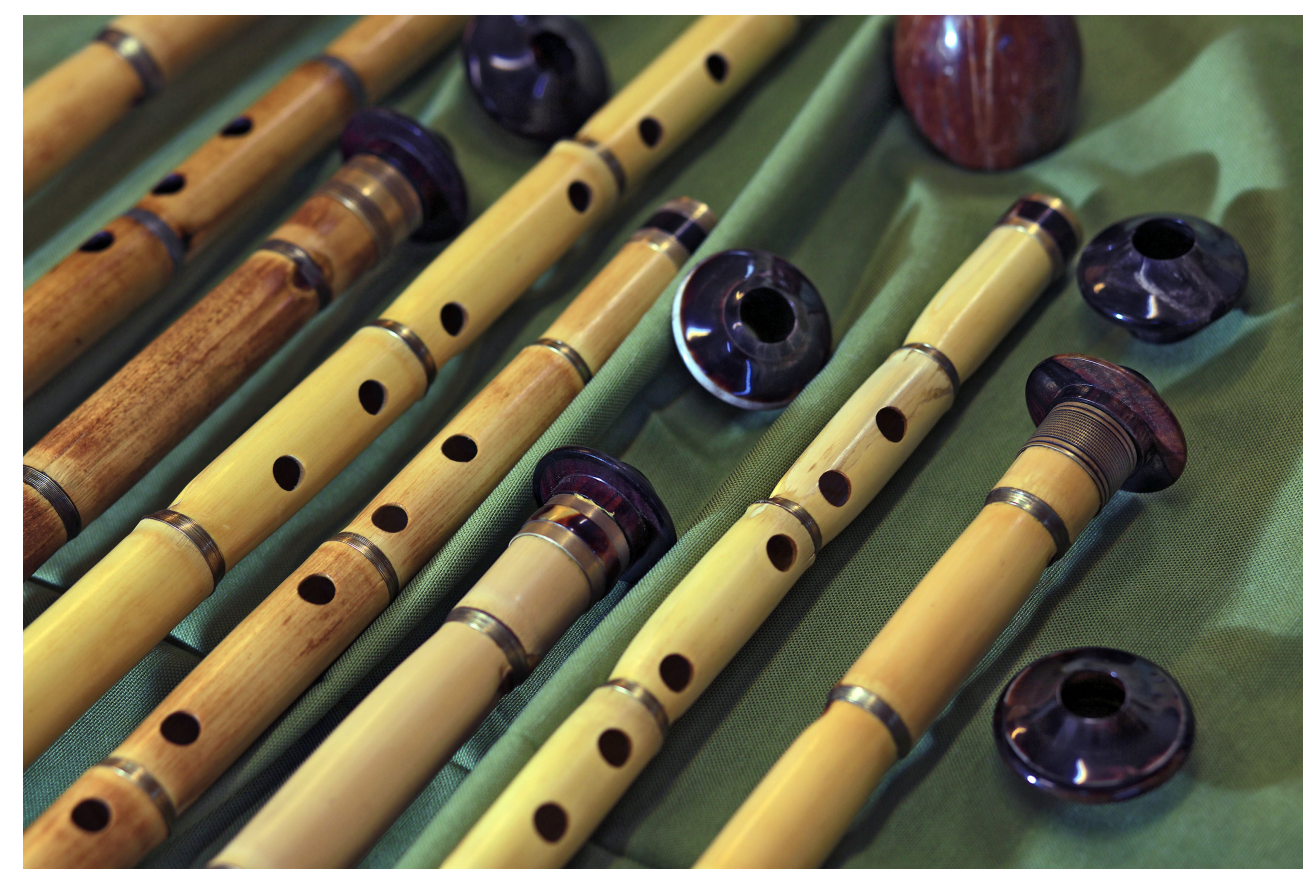

FIgURE 1. Neys ${ }^{6}$ and mouthpieces (başpare) made by Salih Bilgin

Courtesy of Salih Bilgin

5 Perhaps related to these rather extravagant claims, one common criticism pertains not to the "spiritualization" of the ney per se, but to the overly commercial dimensions of many contemporary answers to the spiritual quest. In Selling Spirituality (2005), Carrette and King examine how spirituality has become a potent commodity in the global marketplace. They argue that the privatization of Asian "wisdom" traditions as 
"spiritual" through "the utilization of the wholesome and life-affirming connotations of the term" (2005: 28) has resulted in the emergence of "consumer-oriented and individualized spiritualities" (Ibid.: 29). Kimberley Lau describes this corporate coopting of the "Eastern spiritual traditions" as "New Age capitalism." In light of this, can this bourgeoning demand for ney-playing be best understood as linked to the flourishing of a ney market driven by commercial motivations? To put it differently, does the denoting of this musical activity as "spiritual" instrumentally relate to a widespread "market mentality" whereby individual entrepreneurs strive to improve the success of their teaching and thus of their market share, as has been claimed for some other in-demand spiritual practices such as yoga and t'ai chi (Jain 2014; Lau 2000)?

6 In brief, these varied claims concerning the spiritual powers of the ney circulate more widely than ever in its "golden age," leading to its re-contextualization as at once both a musical and spiritual tool. In the first part of the paper I discuss some of the key cultural and political processes contributing to this hearing of the ney as the "spiritual" sound par excellence. They include both the creation and consumption of new musical genres such as "Sufi music" and world music, and the reinvigoration of Mevlevi-inspired Sufi practices as sponsored by both state and private actors in Turkey. By contrast, in the second half of this paper I discuss how, for at least one group of ney masters, the transformative potential (artistic, ethical and spiritual) of this musical practice is not situated in the sounds of the object itself - at least, not in the ney alone - but is grounded primarily in learning the art in a certain way. The pedagogical practice of these ney masters often involves a minimizing and even a critique of this spiritualization of the ney whether commercial- or state-sponsored, focusing instead on the musical skills and perceptual modifications that are involved in its learning. Here a different and more modest connection between spirituality and ney-playing is constructed, one that is embedded in the learning relationship between hoca [master, teacher] and talebe [pupil; one who demands knowledge]. ${ }^{7}$

7 My argument draws upon fieldwork carried out in Istanbul between 2011 and 2014, which involved, in the first place, my own exposure to ney-learning at the Hezarfen Ney School in Istanbul's Üsküdar district, where I worked with Neyzen Salih Bilgin (b. 1960), a talebe of legendary Neyzen Niyazi Sayın (b. 1927), for fifteen months over a three-year period. These lessons were delivered in a group-teaching setting. ${ }^{8}$ Additionally, fieldwork also involved observations at a wide variety of sites of pedagogy in Istanbul as well as in-depth interviews with diverse groups of ney musicians, masters, and skilled learners. ${ }^{9}$ Let me first draw out more fully the links between spirituality and the ney revival, discussing both the discursive dimensions of this relationship, as well as its historical connections. 


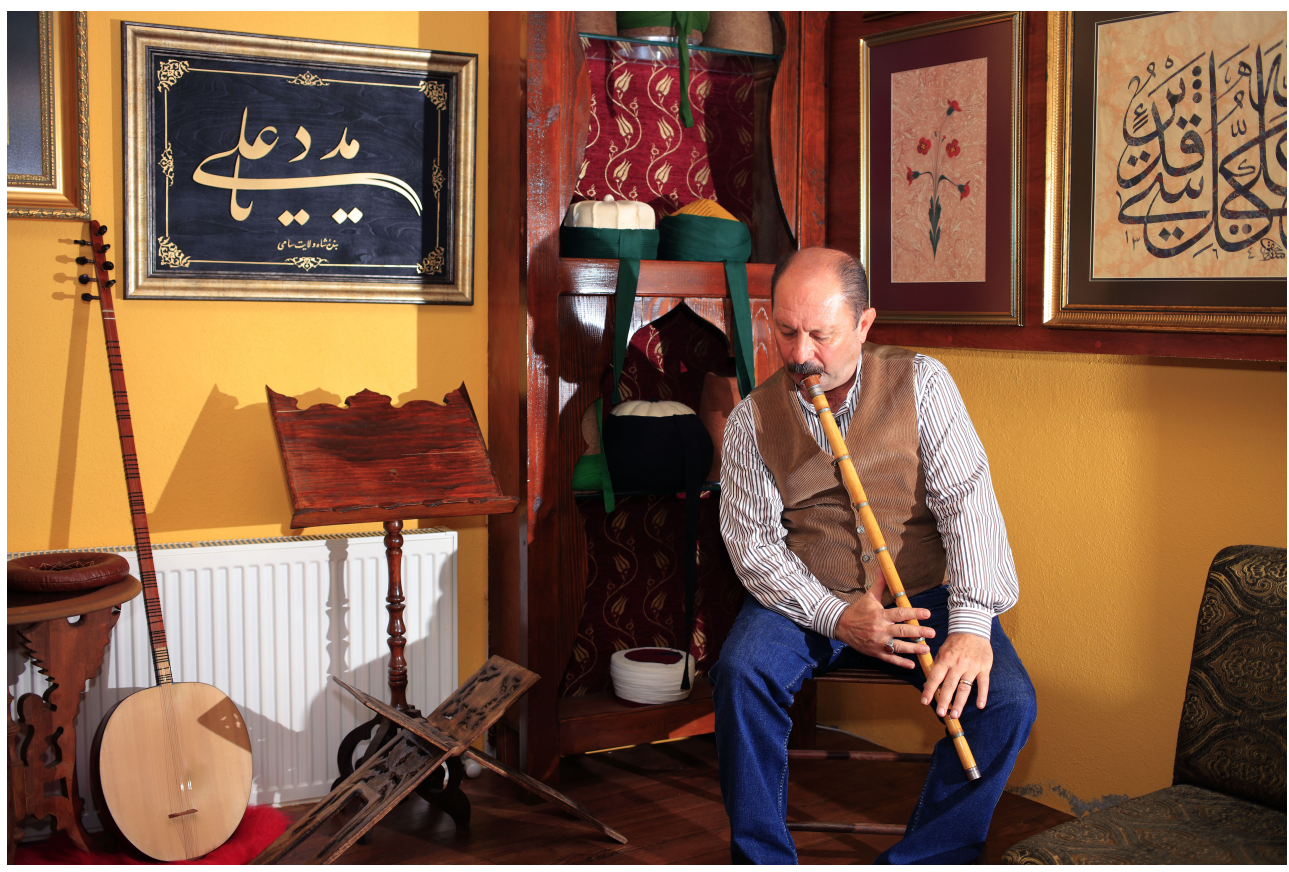

Figure 2. Neyzen Salih Bilgin

Courtesy of Salih Bilgin

\section{The spiritualization of the ney}

Some instruments in the late $20^{\text {th }}$ century operate as indispensable ingredients of artistic expression simultaneously at the levels of culture, commerce and creativity. They are now part of a global cultural economy and circulate in transnational networks of practice, commodities and aesthetics (Neuenfeldt 1998: 5).

The public life of the ney over the last decade provides us with an excellent illustration of the transformation of "old instruments" that find themselves in "new contexts", as described above by Karl Neuenfeldt. Although the artistic tradition of ney-playing had a rich history in the Ottoman Empire, and a more chequered one in the first 50 years of the Turkish Republic (şenay 2014), it is in the last ten years or so that the ney has truly captured the national musical imagination. In Turkey, the growing popularity of the instrument is not just limited to Istanbul, a city that has always been the heartland of cultural production in Turkey, but has occurred in other urban centres too, leading to an exponential growth of ney performances, and a huge demand for ney-learning (Ibid.). Neys are now made and sold in such large quantities that local authorities in Turkey's southeast city of Hatay sought to organize "special protection" for the reeds growing in the area given the increasing competition in reed-harvesting, often resulting in the cutting of pre-mature reeds. Despite this the Governor of the city proudly stated in an interview that Hatay reeds are in demand even from places as far away as the United States and Japan. ${ }^{10}$

What is clear is that the ney is not the only wind instrument that has experienced global popularity in the late twentieth century. As a growing body of writings in ethnomusicology have observed, many other flute traditions (but not all) have been entangled in similar processes of spiritualization. Take the Japanese bamboo flute the shakuhachi, for example. The incorporation of its sound into a wide range of musical expressions dubbed as "world music," and a massive demand for shakuhachi-learning 
(especially outside Japan) are described as recent salient features of contemporary shakuhachi music (Keister 2004; 2005; Matsunobu 2011). Why is this the case? What makes some flutes more disposed to the sensibilities of transnational networks of musicians, audiences, consumers and market forces (Baumann 2000) than others? Jay Keister (2004: 100) explains that "a key factor in the overseas success of the shakuhachi is precisely its historical links to Buddhism and the ease with which philosophical ideas based on Zen can be articulated or felt through the instrument." The Western appreciation of Zen Buddhism as an individualistic spiritual tradition has facilitated a substantial demand for shakuhachi where keen learners take up the learning of the flute for spiritual and meditative purposes (see Matsunobu 2011). According to Keister, most learners, being uninterested in the broader musical tradition that incorporates the instrument, "follow a more individualistic and self-determined path that is free of any social constraints imposed by a teacher or a tradition" (2005: 47).

Despite their origin in different geographical and cultural milieu, there are vital similarities between the transnational spirituality of the shakuhachi and the ney in the present (for a comparison of their histories, see Ribble 2003). If the history of the shakuhachi as an instrument of Buddhist meditation makes it appealing to the spiritual seeker (Keister 2005: 47), so too does the Sufi background of the ney. Historically, the artistic tradition of ney-playing occupied a pivotal role in the musical and devotional practices of Ottoman Sufi orders, especially of the Mevleviye, instituted after Mevlana Jalal ad-Din Rumi (d. 1273). The ney's service to the main ritual activity of this order, which integrated music and the sema dance of dervishes (renowned more popularly as whirling dervishes) is a major part of its biography (see Feldman 1996: 187-92; Feldman 2001). The dervish lodges, especially those of the Mevlevis, played a key role in facilitating the teaching and performance of the instrument, a spatial relationship that continued until the prohibition of Sufi orders in 1925 by the Turkish Republic.

11 Further, alongside the spiritual associations attributed to its music, the ney has an evocative poetic relationship with Sufi Islam. The mystic poetry of Islam is rich with analogies that disclose or express the soul's yearning to be reunited with God. Jalal adDin Rumi bestows this same desire on the reed flute. His poetic work, Mesnevi, opens with the lines:

Listen to this reed, how it complains:

it is telling a tale of separations.

Saying,

Ever since I was parted from the reed-bed,

man and woman have moaned in (unison with) my lament

.. .11

12 According to Rumi's analogy, the sorrow of the ney/human being is its longing for reunification with its original source, the Divine, and this archetypal longing is the "secret" whispered by the ney.

Although the influence of Rumi's poetry is not new, in the current context of the reinvigoration of Mevlevi spirituality both in Turkey and globally (Vicente 2007), Rumi's words circulate ever more widely. Indeed, my research showed that many enthusiasts were inspired to play the ney (and so-called Sufi music) after their contact with Rumi's writings or following their interest in Sufism (tasavvuf). In a questionnaire I handed out to students in one teaching site sponsored by Fatih Municipality (in Istanbul), nearly one-third of the students (out of 38 members) reported an interest in attending Mesnevi related activities run at various religious associations around the 
city. I was told by one female member of this group (aged 23) that she would not have considered participating in any musical activity apart from the ney. "The ney is different from other instruments," she said, adding: "It is the only instrument that constitutes a philosophy" (felsefesi olan tek enstrüman). The unique spiritual identity attributed to the ney distinguishes it from other instruments of Ottoman-Turkish classical music. Even a quick survey of ney-related websites, newspapers, magazines (see the Ney magazine dedicated for ney students), concert publicity, and CD recordings reveals the generation and dissemination of a widespread discourse about the "spiritual ney." 12

14 A close connection exists between this "spiritualization" of the instrument and contemporary artistic and commercial developments in the global and Turkish music industry. Following the successful marketing of Turkish "Sufi music" as a sub-genre of "world music" in the mid-1990s (see Değirmenci 2013; şenay 2015), the ney has been insinuated into a highly eclectic range of musical styles categorized and sold under such a label. ${ }^{13}$ The sound of the ney and the image of a whirling dervish are often utilized as the sonic and visual signifiers of this new musical genre. According to Phillip Bohlman, the issue at stake here is much more than the categorization of those musical expressions as "Sufi" by the music industry, but pertains more fundamentally to the shifting ownership of Sufi musical practice. He writes that, "Sufism, as a category, in and of itself, stripped of local practice and the meanings conveyed through the individualized genealogies descended from specific sheikhs, has taken a place in the global imagination as a world religion" (Bohlmann 1997: 62). Bohlmann rightly points out how "ownership has passed to the consumer of the music with the transformation of religious music to spiritual music", and that one needs to be neither Muslim nor religious in order to "penetrate the spirituality that Sufi music conveys" (Ibid.: 67). ${ }^{14}$

Yet consumers are not the only "owners" of this re-created Sufi music that finds appeal today. One key player absent in this explanation is the Turkish state and analysis of the ways in which it too has claimed ownership of "sufi-music." Paradoxically, despite the continuing prohibition of Sufi orders by law, today the Ministry of Culture and Tourism appears to be the most vigorous promoter of Mevlevi-inspired Sufi music (see Vicente 2007). As Béatrice Hendrich (2011) notes, "The example of the Mevleviye shows that the ban of the mystical orders in 1925 resulted in both the end of 'traditional sufism' in Turkey and the emergence of new organizational forms". These new organizational forms include, among other things, the state's authorizing in 1990 of its own dervish group under its Ministry of Culture and Tourism. The sema ceremonies held every December constitute the biggest international event not only in the city of Konya where Mevlana's mausoleum and the Mevlana Museum (the central Mevlevi lodge previously) are located, but in the whole country. As Gamard (2010: 119) notes, these public events generate rich income for the government, given that "1.3 million Turkish and foreign (generally about 25 per cent) visitors bought museum tickets during 2006." The economic gains garnered from the touristification of Mevlevi-Sufism play a pivotal role in this state-sponsored nationalistic spirituality.

These processes of touristification, commodification and nationalisation of Mevlevi musical practices sponsored by both private and state actors in Turkey constitute an important social context through which the ney interacts with its audiences. In Turkey's first underwater museum established by the local chamber of commerce in the Mediterranean city of Antalya, two Mevlevi dervishes - one is a ney player - 
showcase their "spiritual" practice for adventurist divers. The dervishes sit under water together with a hundred other giant sculptures crafted to represent themes of national importance (see fig. 3).

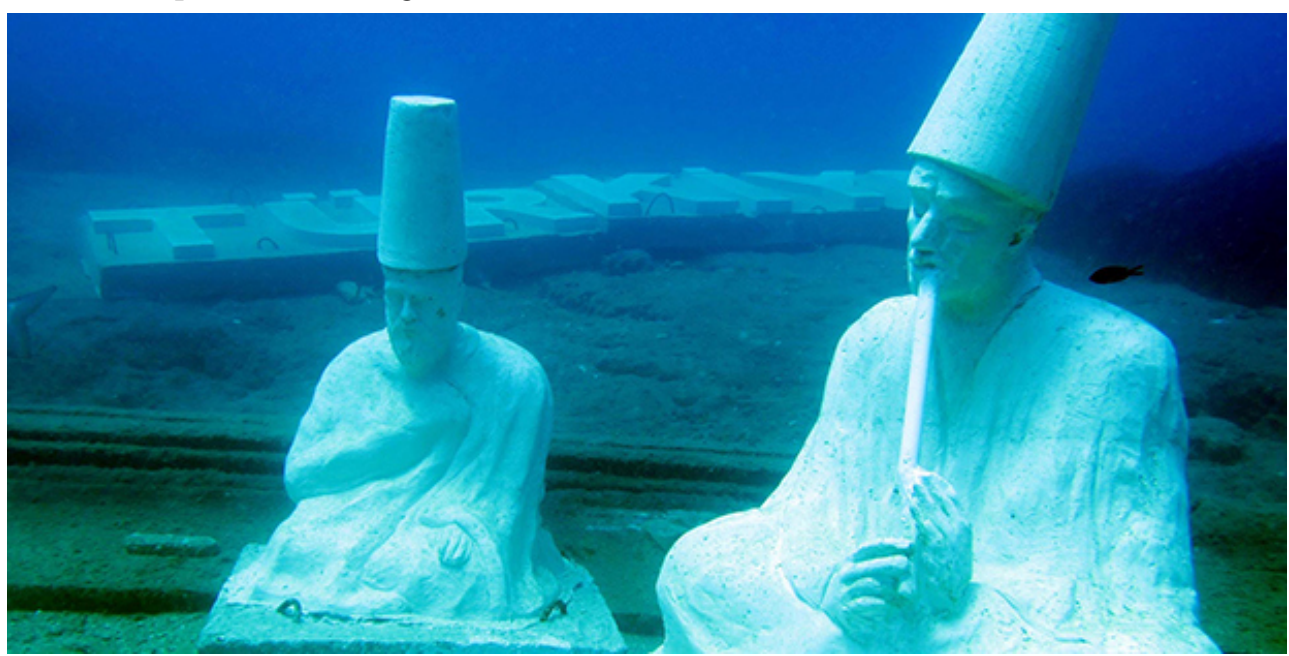

FiguRE 3. The sculptures of two Mevlevi dervishes displayed at Side Underwater Museum ${ }^{15}$

The commodification of the ney as a "spiritual" object, and a "consumerist mentality" that rushes through a ney curriculum while manipulating symbols or themes of Sufi spirituality, were frequently debated by ney musicians at the time of my fieldwork (2011-2014), which involved my own ney-learning at an Istanbul-based studio, observations at a wide variety of sites of pedagogy (e.g. private workshops, councilsponsored courses, music associations) and in-depth interviews with diverse groups of ney musicians and learners. In this second half of the paper, I continue to examine the kinds of spiritual experiences and practices that surround the ney, but this time by looking at its teaching and learning. The analysis concentrates specifically on the pedagogical practices of ney masters who are members of the two major ney lineages (silsile) in Turkey that trace their genealogy back to the Ottoman period. ${ }^{16}$ Nearly all were critical of the current efflorescence of the ney and Sufi music in Turkey. For them, the transformative efficacy of this skilled practice lies in learning to play the ney in a particular way through the apprenticeship process and practice of meşk (Behar 1987; 1998), rooted in the relationship between hoca and talebe. At the centre for the pedagogy of meşk lies the student's voluntary surrender and fidelity to a master who guides the musical disciplining of the apprentice and grafts them into a certain artistic lineage through which the core elements of an aesthetic style are handed down. Learning in this style encompasses more than particular ways of knowing music through the transmission of an artistic style, repertoire, and musical knowledge: it also involves the shaping and modification of learners' ethical sensibilities. Further, in meşk the learning of the ney is not the main thing: music lessons are subordinated to other imperatives in the pedagogy, the most important of which is the intimate masterstudent-relationship itself.

\section{The spiritual power of the hoca-talebe relationship}

The person you take lessons from may not always end up becoming your hoca, and not every person you teach may become your talebe. Learning to play the ney is a technical endeavour. You learn how to move your fingers, your lips, this and that. 
Anyone can learn those things if she or he commits time on practice. What matters

more is the connection [irtibat] between the hoca and talebe. (Salih Bilgin) its emphasis on fidelity, surrender and dedication, and the mürsid-mürid relationship found in Sufi disciplinary practices. As the living link to the spiritual knowledge transmitted within the tariqa, the mürşid [spiritual guide] instructs the mürid [disciple] on the Sufi path, by "tuning" the disciple through different stages of spiritual disciplining, leaning towards intimacy with God (Werbner 2003: 21). Examining the spiritual kinship relations among Sufi disciples in modern South Asia, Werbner shows in Pilgrims of Love how the mürid's cultivation of subjectivity based on submission, self-denial, and service to the mürşid (and to the larger community) is essential for achieving ethical and spiritual development. She writes that it is the "interpersonal loyalty and feelings of deep affection between disciple and sheikh" (Ibid.: 169) that are capable of generating emotions of courage, happiness, "a sense of real achievement" and solidarity for disciples, "endowing the lives of such men with a redemptive sociality" even away from the saint's lodge (Ibid: 134). Similarly, Qureshi describes the mürşid-mürid bonding as one of a "guidance relationship." "The feelings of reciprocal trust and deep affection among the two subjects are essential for the disciplinary practice," she notes (2003: 63).

In the musical practice examined here, too, the feelings of devotion and surrender on the part of the learner are a fundamental requisite of a possible hoca-talebe relationship. Importantly, this emotional content of the relationship serves as a vital "learning mechanism" (Milton 2002). As Gieser (2008: 299) discusses, the emotions cultivated in the apprenticeship context do not merely form a backdrop to learning. Instead, emotions carry an active force, enabling the novice to "enter into an empathic relationship with a skilled practitioner." As one ney musician who was taught by Neyzen Salih Bilgin stated:

May God bless my Hoca. I completely surrendered myself to him. To be in such state of surrender is very important in meşk. Only then muhabbet (spiritual love) occurs. This intense emotional bond [duygu bağl] is very important in meşk. You pay your hoca the respect that you may not even pay to your own father. 
During our conversations, ney masters frequently used the word muhabbet to describe the strong affective relationship they established with their own teachers. Muhabbet, meaning spiritual love, is what emerges from the "direct communion", and the "intimate rapport between the master and the pupil" (Maitra 1977: 220 cited in Kippen 1988: 107). According to Frances Trix, muhabbet can also be understood as a state of "attunement", as she discusses in relation to the mürşid-mürid relationship in the Bektashi order. Trix (1993: 150) underlines the point that learning through this relationship is imperative for "an increasing coordination of hearts, with heart understood as the seat of higher faculties of perception." Muhabbet can be best understood then as both an emotion, and a capacity to be influenced (emotionally and intellectually) by one's teacher. Being in the presence of one's master, sitting side by side with them, and embodied exposure to their verbal and non-verbal acts are all imperative for creative becoming.

\section{Spirituality as Kinship}

22 An important dimension of learning through the hoca-talebe relationship is that by instituting a context in which the novice learns directly from one master, the pedagogy grafts the learner into a certain lineage (silsile), or what Eickelman refers to as "quasigenealogical chains of authority" (1978: 492). When the transmission of OttomanTurkish classical music is concerned, becoming a member of an established lineage of musicians still continues to be a crucial aspect of one's socio-musical identity; whom one has studied with and to which artistic lineage one belongs constitutes a major source of social and symbolic capital - as well as of prestige and pride - in the life of a skilled practitioner. Because ontologically the hoca is understood to be the embodiment of "tradition" (gelenek), it is through one's pedagogical relationship with the master that one establishes his or her own connection to the tradition. As one ney master teaching at a music department of an Istanbul university remarked:

Neyzens must belong to a lineage, a meșk lineage. It is a problem if one cannot trace the masters of their own master back to two or three generations ago. This music can only be learnt from a master, who must have also learnt it from their master. It is the lineage that constitutes this tradition. By contrast, in popular music, musicians exist without any lineage, but merely as individuals (interview with Neyzen Ali Tan, 5 June 2012)

Belonging to an artistic lineage creates musical and "spiritual kinship" (Qureshi 2003) relations among its members, connecting the living to the dead members of that kin group. As in Sufism, ney masters often talk about their lineage as a yol [way or path]. "Our way goes back to [Armenian] Oskiyan Efendi" pronounced the great Neyzen Niyazi Sayin referencing his own kinship, which constitutes the most prestigious lineage of neyzen masters in Turkey today. Although a complete genealogy cannot be recited, Sayin is able to trace his musical ancestry back five generations, providing a family of musicians including his own master Halil Dikmen (1906-1964), Emin (Yazıc1) Dede (1883-1945), Aziz Dede (1835-1905); Sâlim Bey (1829?-1885), and Tanburi Oskiyan (d. 1870). The three nineteenth century members of this lineage practised their art in a social milieu in which Sufi tekkes were still active. Sâlim Bey had been initiated into the Sâdiyye tariqa, yet he was also a muhibbi [sympathiser] of the Mevlevi order. Aziz Dede, on the other hand, was a Mevlevi dervish, and served as the head ney master of Istanbul's three Mevlevi Convents, including Galata, Üsküdar and Bahariye. His talebe 
Emin Dede, too, was a Mevlevi, who continued his service as the last head ney master of the Galata Mevlevi Convent until its closing down in 1925 (for biographical information see, Ergun 1942; Ayvazoğlu 2008).

For at least some ney masters, lineage means more than just an "imagined community." At the Hezarfen Ney School, the musical compositions of lineage members occupied a significant place in the selection of repertoire that were assigned to students. A code of ethics applied here. According to Neyzen Salih Bilgin, students ought to feel morally responsible for mastering the particular repertory of neyzen composers. In his words, this was "an act of contemplation (tefekkür)" and of "showing indebtedness" to now dead members of the meşk lineages. In his ney lessons, Bilgin would occasionally allude to anecdotal stories about his lineage members, who were talked about like members of an extended family. Having been taught and guided by Niyazi Sayın, Salih Hoca himself was identified with the artistic lineage mentioned above.

Finally, the metaphor of yol implies more than descent from individual members of a musical-spiritual kinship group. It implicates also a "way of doing", encompassing shared elements that give a family of musicians its idiosyncratic image, amongst which a style of playing (üslub) is most defining. To become a member of a lineage requires a socialization of the student into the shared üslub, including technical knowledge and artistic articulations, as well as into a certain repertory. In other words, the talebe's attention needs to be modified to cultivate in them a particular way of hearing and playing, consistent with the fundamental traits of the lineage's style. As such, skilled learning involves students in a series of "intentional modifications", changes in the way the "aural perceptions" of the novice develop dispositions of "hearing as" (Duranti 2009: 210). In facilitating this, the institution of the pedagogy helps maintain a stylistic consistency within meșk lineages. As Silver (1976: 50) notes in relation to the IndoPakistani musical context, the kinship relations among lineage members serve as "an effective and controlled federation of internally consistent stylistic pools among which there is a cautious but ultimately enriching series of coalescences in the development of each individual musician." This does not suggest that the tradition passed down through the lineage is fixed and unchanging. By contrast, each lineage member recreates the musical style - this applies also to the teaching practice - but only when they are disciplined thoroughly in the fundamental techniques of the art and musical repertoire. Where ney music is concerned, the dynamic nature of the tradition is best exemplified in the artistry of Neyzen Niyazi Sayın. The new technical and aesthetic possibilities that Sayın brought to the art of ney-playing led to the emergence of a new distinct style named after him.

\section{Spirituality as Ethical Character-Formation}

The process of becoming a practitioner of the ney entails, in addition to embodying certain physical skills, the "education of attention" (Ingold 2001: 142) in a whole range of other practices that in many respects are extra-musical. Apprenticeship, in this sense, "involves the body in ways beyond technical competence" (Qureshi 2000: 808) and is more akin to a practice of character-formation. Mastering a musical instrument, a craft, a form of dance, or a martial art involves at the same time cultivation of a particular kind of self. Bryant underlines this point in her study of students in Istanbul who are learning the bağlama, a type of long-necked lute iconic of folk music in Turkey, 
arguing that apprenticeship involves not just mastery of the instrument but also composition of a personality capable of playing it. She calls this a process of "empersonment", "learning to become the type of person who can do X" (2005: 233).

At the heart of the skilled learning activity analyzed here lies a conviction that one becomes a good ney player not merely by becoming proficient in its technical mastery but, over and beyond that, in developing ethical sensibilities that are required to embody the art of being a true neyzen. As we shall see in the self-reflexive narratives of ney masters provided below, alongside their musical disciplining, an experience of ethical character-formation is integral to their creative becoming whereby a spiritual meaning is found. Spirituality, in this sense, is concerned with how musical education cultivates, shapes or modifies various dispositions in players' moral selves.

Ney masters agree that there is an inextricable link between art and ethics in musical learning. Artistic practice is not understood as an end in itself; it also serves for the attainment of a moral goal. Virtuosity cannot occur without the cultivation of inner virtues. Ibn Khaldun's conception of malakat [habitus] illuminates this dialectical relationship. According to Khaldun, the competent performance of any skilled activity - calligraphy, carpentry, minaret building - furnishes the soul with attributes, which through practice and repetition forms a habit (Lapidus 1984: 53-54). A habit, malaka in Arabic, is more than just a learned semiautomatic activity. It bears the meaning of habitus - an acquired faculty, rooted in the soul. Each activity "gives the soul a special colouring that forms it" (Ibid.: 53). As neyzen Sadrettin Özçimi explains:

Meşk is not just teaching an artistic skill. It involves also teaching the talebe the spirituality, the ethics of that art and guiding them in realising what art essentially serves for. We know that these art traditions [referring to calligraphy and music] were used in the tekkes in the past with the aims of softening the soul and giving it a form. Can you shape hard dough? This is what arts were intended for, to mould the human heart. If you are able to use arts for this purpose, then it becomes a correct [doğru], a beautiful [güzel] art.

Özçimi offers a conception of musical learning as a form of moral education that ideally "foregrounds the role of virtuous character in the good life" (Kristjánsson 2013: 272) through an enabling of certain moral sensibilities in the talebe. Through apprenticeship one learns not only "how to do" but also "how to be." As Karakayalı (2010: 351) states, "Learning is not merely about the training of auditory and tactile senses of the musical apprentice; the "habits" and "memory" engendered as a result of these repetitive sessions encompass many activities ranging from proper manners of sitting and expressing emotions, to the ways of listening, playing and appreciating music." The quote below by Ali Tüfekçi, a neyzen who teaches at the State Conservatoire at Istanbul Technical University, reveals how one's manners of sitting, standing, and listening carry as much weight as one's musical skills and proficiency when it comes to judging who is an ideal talebe.

The conservatorium has changed a lot, what being a talebe means has changed too. When we were students, you learnt through the master-apprentice relationship. But now there is a 14-week curriculum and a student knows which makam is to be covered, say, in week seven. Some hocas are trying hard to preserve meşk, but the system isn't allowing us to teach like that anymore. Everything has become standardized, so have the talebes and the pitches (perdeler) they play. There is no love (aşk yok), just an artificial meşk (sadece suni bir meşk). But of course exceptional talebes exist. Currently, I am working with eight students and one of them signals that he has the potential to become a good talebe. When I look at him, I see my own 
earlier self. The way he sits, the way he walks - he always leaves the room walking with his back towards the corridor - his character (karakter), his expression of respect for his hoca, his polite manners and modesty. Unlike other students, he doesn't ask questions like "Hocam, what are we doing next week?" He is patient and meticulous.

Note here how the understanding of an ideal talebe is closely tied to a repertoire of virtues embedded in a certain mode of comportment, etiquette and manners, all of which have an ethical import. The bodily "signs" that the student is said to give away, which ultimately make him stand out amongst the cohort of students Tüfekçi is working with, are related in the first place not to his adeptness of skill, but concern precisely his ways of holding his body, style of expression, listening mannerisms and ways of acting, each imparting a morally sound intent. In recounting the virtues that he recognizes in his student's embodied presence and actions, Tüfekçi is not framing them as a mere reflection of the person's moral character, but as a certain kind of attitude towards practice. It is through such gestures and actions that the talebe demonstrates a genuine intention, a "seriousness" of purpose in becoming a committed talebe. To demonstrate a capacity to comport the body in a fitting manner is to intentionally orient oneself towards the act of learning - a comportment towards learning. Without such orientation or attitude, how can learning be effectively - and affectively achieved?

An essential term that master musicians often use to talk about manners, etiquette, and correct behaviour is adab, the development of which, according to Ibn Khaldun, forms "the malaka of the whole person" (Lapidus 1984: 56). Although the term appears to be primarily about "outer" manners, inner qualities cannot be separated from conduct, for "knowledge is not true knowledge unless it is realized" (Metcalf 1984: 9).

In what ways does skilled learning facilitate the talebe's cultivation of the adab required in this art? Given that the hoca-talebe relationship is the immediate context of teaching and learning in this pedagogical practice, spending time with the master during and outside of the actual lesson time is in itself conducive for such embodied disciplining. As the autobiographical reflections that interviews with ney musicians revealed, the masters they learnt from fulfilled in their lives, above all else, the role of an exemplar, providing them with a model of acting worthy of emulation. They not only taught but inspired their pupils, facilitating their moral growth as much as guiding them through the intricacies of the art. Faubion's account of "ethical becoming" is useful here, in which he defines it as a process that involves not just individual subjects' rule-abiding, but concerns more broadly the ways in which one comes to occupy a certain subject position well. For Faubion, pedagogues do more than set out certain normative rules to be followed by others; because they come to inhabit their subject positions in a skilful manner, they are able to act as an exemplar with a capacity to convey values and ideals concerning how to live (2011: 51-52). This point can help us consider the subtleties of the hoca-talebe relationship by shedding light on the ways in which this interpersonal relationship can be empowering for both subjects even if it is deeply hierarchical. It is legitimate to argue that masters performed an exemplary role in the lives of their talebes who surrendered to them, not by putting in place rules to be followed by their disciples, but by occupying well their own subject positions as a hoca in the first place. Alongside their virtuosity, in their comportment, demeanour, rhetoric and actions they were seen worthy of emulation, capable of "serving at once as existential guide" (Foucault 1997: 233-4). 
33 Musicians often use the expression feyz almak [to receive feyz] when they describe their experience of musical learning. This multi-textured word refers to the state of being greatly inspired and influenced by an exemplary guide. Its more literal meaning in Sufism implies a light emanating from someone, a powerful force that spreads from one heart to another, as well as to be affected by one's spiritual power. Although there are no prescribed ways through which feyz can be received, sitting side by side with a guide and listening to their words are conceived as particularly vital for creating a certain shared affective state between the two subjects. According to Salih Bilgin:

If you genuinely seek to learn something and spend a lot of time with a true instructor [mürebbi], the aura of that person emanates in you [o kişinin kokusu sende zuhur ediyor]. In reality, that person does not teach you; instead their knowledge becomes manifest in you. We are all intermediaries in this art.

34 A closer look at the teaching practice of Neyzen Niyazi Sayın might give us some clues about how character training is a vital dimension in this mode of teaching/learning. Let us refer to the experience of Sadrettin Özçimi, who had been subject to the morally transformative potential of this artistic practice through learning from Sayın:

We used to gather once a week on Wednesdays around eight o'clock and we would continue way into 4 or 5 am of the following day. We were there to play the ney with our hoca, right? But believe me, the time spent for playing the ney in that 6-7 hour lesson would hardly make half an hour. Apart from that, there was always sohbet [conversation]. There was sohbet about Sufism, about music. Hoca passed on many things to us about his own hoca, about the great musicians of his time, and about the Sufi elders he knew. We obtained a lot of criteria [ölçü] from those sohbets. Humanistic criteria. This is how our lessons passed. I mean, meşk was not just about playing the Rast peşrev. A talebe should try to learn not only the actual art from their hoca, but the spiritual and ethical dimensions of that art as well. Then meşk happens (Interview with Sadrettin Özçimi, 7 June 2012).

Özçimi, who took his formal musical training at the Conservatory of Istanbul Technical University in the late 1970s under the guidance of Neyzen Aka Gündüz Kutbay (1935-1979) and Niyazi Sayın, emphasizes here how his lessons were rarely about playing the ney. His words reveal the significance of the unmediated presence of the hoca-talebe and exposure to Sayın's sohbets. Another renowned talebe of Sayın, Neyzen Ömer Erdoğdular (b. 1949) recounts:

I started going to Niyazi Hoca in 1965. He used to live in Üsküdar then, in an old, two-storey, wooden house remaining from his father. He used to live there together with his mother, elder sister and his sister's daughter. That's where we had lessons. Initially we used to come together on Sundays. Back then, there was this famous şan Sineması in Taksim where Münir Nurettin Selçuk used to perform every second weekend. Because Niyazi Hoca used to take part in those concerts, we would go to his house once a fortnight. Later we shifted the lessons to weekday. Niyazi Hoca is a profoundly knowledgeable person of course. He had been acquainted with venerable men from the late Ottoman era. He would tell us about the Mevlevi dervish, Sucu Ali Fâni Dede and Eşref Efendi whom he deeply revered. At the time of his growing up, there was Nafiz Uncu Efendi in Üsküdar, the imam of the İskele Mosque, and the renowned calligrapher Necmettin Okyay who was the imam of the Yeni Valide Mosque then. Both were great hafiz of their time. Niyazi Hoca knew them well and in his sohbets he would tell us a great deal about these figures who had so much influence on his life.

Niyazi Hoca was extremely generous, extremely hospitable towards us. Visitors were never absent in his house. It is that generosity, those morals [ahlak] of him that give the sound of his ney its character. When we went to him for lessons, he 
wouldn't even let us take him a box of lokum, let alone money. "Come with empty hands," he used to tell us. He expected nothing, but only gave. It is his morals that make the sound of his ney (Interview with Neyzen Ömer Erdoğdular, 14 June 2012).

These narratives bespeak a powerful learning experience grounded in emotions of deep respect for not only Sayın's musical brilliance, but for his human excellence also. The intimate relationship between artistic skill and exemplary ethics is also linguistically manifest in the meşk terminology, illustrated in the following expressions used for describing the subject position of a hoca: insan-ı kâmil [perfect person] and fem-i muhsin [literally, refined mouth]. Another metaphor to note is kutub (qutb in Arabic), borrowed from Sufi theology. In Islamic mysticism, the term (literally, "axis", "pole") denotes the perfect human being who leads the saintly hierarchy. Kutub is "a human manifestation of divine consciousness, only one of which exists in any age, and around whom the spiritual life of the age revolves, that is, through whom spiritual knowledge is gained" (Esposito 2003: 257). The one inhabiting this rank is seen as capable of guiding others in the right direction like a pole-star. As in Sufism, so in the art of ney-playing kutub entails the highest honorific title in the hierarchical structure of neyzen masters (referred to as kutbü'n nâyi, [the pole of the ney]). In the long history of this musical art, only a handful of neyzens are known to have been credited with this title, including, most recently, Neyzen Niyazi Sayın.

\section{Conclusion}

What matters in this endeavour is to show the commitment to stay with one hoca. If the talebe shows that commitment, the hoca will take care of him/her. There is a ney-learning craze these days. Ney lessons have sprung up everywhere. But if my talebe leaves me I never accept him or her back. Because only if we stay on one path, we can move forward. Musical instructions are available everywhere, method books, the Internet, an explosion. But what really matters in this art is to imbibe a style [üslûb], to go after one particular style (Salih Bilgin).

The main conclusion arising from this study of a musical community of practice can be summarized in two essential points. Firstly, in the specific socio-cultural context of the thriving ney/Sufi music scene in Turkey, where the mere existence of the instrument has been politicized as "spiritual" - religiously-oriented or otherwise - an examination of the lived experiences of lineage masters invites attention to an epistemological perspective on spirituality that is grounded, in the first place, in the pedagogical activity rather than in the ney. The critical reflections of these masters transmit a counter-spirituality, as they explicitly minimize the "spiritual" associations of the ney, while foregrounding the series of perceptual modifications that one must go through in order to become a ney player. Many new enthusiasts, whose search for a spiritual dimension to their lives have found in the ney a source of self-transformation, are oblivious to the fact that learning is a slow process, requiring rigorous training of the senses and the body. As a matter of fact, the dropout rate of new learners is extremely high.

Secondly, an analysis of the pedagogical practice described here, of which I was able to provide only a brief snapshot, connects to broader questions around autonomy, selfhood, and submission to authority. Unlike the liberal and neoliberal view that all forms of surrender to an authority figure are at odds with the autonomy of the individual and/or the consumer, the act of surrender essential to this learning practice 
should be understood as imperative for cultivating ethical and spiritual self-formation. In other words, the "spiritual" experience is understood to be constituted out of this relationality - not in the solitary working on the self - the realization of which in itself constitutes an ethical sensibility of humility, understood as a sense of awareness of our dependence on something other than ourselves. In the eyes of at least one group of neyzen masters, it is these ethical, emotional and artistic qualities that make learning through the hoca-talebe relationship the most suitable way of passing down their skilled knowledge. Their critical assessments of certain emerging pedagogical trends and practices for their lack of unmediated contact and exchange between teacher and pupil (i.e. interactive online lessons; method books and ney-teaching DVDs; quick learning that moves through a curriculum until it ends etc.) should be primarily understood in this context, rather than as an attempt, cynical or otherwise, to gain distinction in the crowded field of ney-learning or to preserve a share in its burgeoning market.

\section{BIBLIOGRAPHY}

Aydemir, Alanur (March 13, 2014). "Ney, the 'absolute' instrument of the human soul”, Daily Sabah. URL: http://www.dailysabah.com/feature/2014/03/13/instrument-of-the-human-soulabsolute.

Ayvazoğlu, Beşir (2008). Ney'in Sırrı [Secret of the Ney], Istanbul, Kapı Yayınları.

Baumann, Max P. (2000). "The Local and The Global: Traditional Musical Instruments and Modernization", The World of Music 42(3), p. 121-144.

Behar, Cem (1998). Aşk Olmayınca Meşk Olmaz: Geleneksel Osmanlı/Türk Müziğinde Öğretim ve İntikal [Without Love, There is No Meşk: Education and Transmission in Traditional Ottoman/Turkish Music]. Istanbul, Yapı Kredi Yayınları.

Bessman, Jim (2002). "For this tailor-made virtuoso, the nays have it," Rhythm May 2002. URL: http://www.omarfaruktekbilek.com/for-this-tailor-made-virtuoso-the-nays-have-it/.

Bohlman, Phillip V. (1997). "World Music and World Religious: Whose World?," in Sullivan, Lawrence E., (ed.) Enchanting Powers: Music in the World's Religions, Cambridge, Center for the Study of World Religions, p. 61-90.

Bryant, Rebecca (2005). "The soul danced into the body: nation and improvisation in Istanbul," American Ethnologist 32(2), p. 222-238. DOI: 10.1525/ae.2005.32.2.222.

Carrette, Jeremy R. and King, Richard (2005). Selling Spirituality: The Silent Takeover of Religion, London, Routledge.

Cobussen, Marcel (2008). Thresholds: Rethinking Spirituality through Music, Aldershot, Ashgate.

Dede, Mehmet (2003). “One Truth: Omar Faruk Tekbilek's Sound of Soul,” omarfaruktekbilek.com. URL: http://www.omarfaruktekbilek.com/one-truth-omar-faruk-tekbileks-sound-of-soul/.

Değirmenci, Koray (2013). Creating Global Music in Turkey, Plymouth, Lexington Books. 
Duranti, Alessandro (2009). "The Relevance of Husserl's Theory to Language Socialization," Journal of Linguistic Anthropology 19(2), p. 205-226. URL: http://www.sscnet.ucla.edu/anthro/ faculty/duranti/Duranti.2009.pdf.

Eickelman, Dale F. (1978). "The Art of Memory: Islamic Education and Its Social Reproduction," Comparative Studies in Society and History 20(4), p. 485-516. DOI: 10.1017/S0010417500012536.

Ergun, Sadeddin Nüzhet (1942). Türk Musikisi Antolojisi - Dini Eserler [Anthology of Turkish Music Religious Pieces], Volume I, Istanbul, Istanbul Üniversitesi Edebiyat Fakültesi Yayınları.

Ergüner, Süleyman (2002). Ney Metod [Ney Method], Istanbul, Ergüner Müzik.

Esposito, John L. (2003). The Oxford Dictionary of Islam, New York, Oxford University Press.

Faubion, James D. (2011). An Anthropology of Ethics, Cambridge, Cambridge University Press.

Feld, Steven (1994). "From Schizophonia to Schismogenesis: On the discourses and Commodification Practices of 'World Music' and 'World Beat', 'in Charles Keil and Steven Feld (eds), Music Grooves, Chicago, University of Chicago Press, p. 257-289.

Feldman, Walter (2001). "Music in performance: Who are the whirling dervishes?" in Danielson, V. (ed.), The Garland Encyclopaedia of World Music: The Middle East, vol. 6, London and New York, Routledge, p. 107-111..

Feldman, Walter (1996). Music of the Ottoman Court. Berlin, Verlag für Wissenschaft und Bildung. Foucault, Michel (1997). Ethics: Subjectivity and Truth. Volume 1, New York, The New Press.

Gamard, Ibrahim (2010). "The Popularity of Mawlānā Rumi and the Mawlawi Tradition," Mawlana Rumi Review 1, p. 109-121. URL: http://www.dar-al-masnavi.org/popularity-of-rumi.html.

Gieser, Thorsten (2008). "Embodiment, emotion and empathy: A phenomenological approach to apprenticeship learning," Anthropological Theory 8, p. 299-318. DOI: 10.1177/1463499608093816.

Hendrich, Béatrice (2011). "Introduction - Beyond State Islam: Religiosity and Spirituality in Contemporary Turkey," European Journal of Turkish Studies 13. URL: https://ejts.revues.org/4527.

Ingold, Tim (2001). "From the transmission of representations to the education of attention," in Whitehouse, H. (ed.), The Debated Mind: Evolutionary Psychology versus Ethnography, Oxford, Berg, p. 113-53. URL: http://lchc.ucsd.edu/mca/Paper/ingold/ingold1.htm.

Jain, Andrea (2015). Selling Yoga: From Counterculture to Pop Culture, Oxford, Oxford University Press.

Karakayal1, Nedim (2010). "Two Assemblages of Cultural Transmission: Musicians, Political Actors and Educational Techniques in the Ottoman Empire and Western Europe," Journal of Historical Sociology 23(3), p. 343-371. DOI: 10.1111/j.1467-6443.2010.01377.x.

Keister, Jay (2004). "The Shakuhachi as Spiritual Tool: A Japanese Buddhist Instrument in the West," Asian Music 35(2), p. 99-131. URL: http://www.jstor.org/stable/4098447.

Keister, Jay (2005). "Seeking Authentic Experience: Spirituality in the Western Appropriation of Asian Music," The World of Music 47(3), p. 35-53. URL: http://www.jstor.org/stable/41700006.

King, Anna (1996). “Spirituality: Transformation and Metamorphosis," Religion 26(4), p. 343-351. DOI: $10.1006 /$ reli.1996.0028.

Kippen, James (1988). The Tabla of Lucknow: A cultural analysis of a musical tradition, Cambridge, Cambridge University Press. 
Kristjánsson, Kristján (2013). “Ten Myths about Character, Virtue and Virtue Education - Plus Three Well-Founded Misgivings," British Journal of Educational Studies 61(3), p. 269-287. DOI: 10.1080/00071005.2013.778386.

Lapidus, Ira M. (1984). "Knowledge, Virtue, and Action: the classical Muslim Concept of Adab and the Nature of religious Fulfillment in Islam," in Metcalf, Barbara D. (ed.), Moral Conduct and Authority: The Place of Adab in South Asian Islam, Berkeley, University of California Press, p. 38-61. Lau, Kimberley J. (2000). New Age Capitalism: Making Money East of Eden, Philadelphia, University of Pennsylvania Press.

Matsunobu, Koji (2011). "Spirituality as a Universal Experience of Music: A Case Study of North Americans' Approaches to Japanese Music," Journal of Research in Music Education 59(3), p. 273-289. DOI: $10.1177 / 0022429411414911$.

Metcalf, Barbara D. (1984). "Introduction," in Metcalf, Barbara D. (ed.), Moral Conduct and Authority: The Place of Adab in South Asian Islam. p. 1-20. Berkeley, University of California Press.

Milton, Kay (2002). Loving Nature: Towards an Ecology of Emotion, London, Routledge.

Neuenfeldt, Karl (1998). "Notes on Old Instruments in New Contexts," The World of Music 40(2), p. 5-8.

Poulos, Panagiotis (2011). "Rethinking Orality in Turkish Classical Music: A Genealogy of Contemporary Musical Assemblages," Middle East Journal of Culture and Communication 4(2), p. 164183. DOI: $10.1163 / 187398611 X 571337$.

Ribble, Daniel B. (2003). "The Shakuhachi and the Ney: A Comparison of Two Flutes from the Far Reaches of Asia,” 高知医科大学紀要 19, p. 1-13. URL: http://www.shakuhachi.com/K-RibbleShakuhachiandNey.pdf.

Qureshi, Regula (2003). "Lineage, Shrine, Qawwali, and Study Circle: Spiritual kinship in transnational Sufism," Religious Studies and Theology 22(1), p. 63-84. DOI: 10.1558/rsth.v22i1.63.

Qureshi, Regula (2000). "How does music mean? Embodied memories and the politics of affect in the Indian 'sarangi',” American Ethnologist 27(4), p. 805-838. URL: http://www.jstor.org/stable/ 647396.

Schimmel, Annemarie (1975). Mystical Dimensions of Islam, Chapel Hill, The University of North Carolina Press.

Sevinç, Kenan, Güven, Metin and Yeşilyurt, Tuğba (2015). “Dindar ve Spiritüel Olmama (DISOL) Ölçeğinin Türkiye'ye Uyarlanması,” Çanakkale Onsekiz Mart Üniversitesi İlahiyat Fakültesi Dergisi 6, p. 59-86. URL: http://dergipark.ulakbim.gov.tr/comuifd/article/view/5000146350.

Silver, Brian (1976). "On Becoming an Ustād: Six Life Sketches in the Evolution of a Gharānā," Asian Music 7, p. 27-58. URL: http://www.jstor.org/stable/833788.

Şenay, Banu (2015). “Artists, antagonisms and the ney in the popularization of 'Sufi Music' in Turkey,” European Journal of Cultural Studies 18, p. 52-69. DOI: 10.1177/1367549414557805.

Şenay, Banu (2014). "The Fall and Rise of the Ney: From the Sufi Lodge to the World Stage," Ethnomusicology Forum 23(3), p. 405-424. DOI: 10.1080/17411912.2014.924383.

Trix, Frances (1993). Spiritual Discourse: Learning with an Islamic Master. Philadelphia, University of Pennsylvania Press. 
Van der Veer, Peter (2009). "Spirituality in Modern Society," Social Research 76(4), p. 1097-1120. URL: http://www.mmg.mpg.de/fileadmin/user_upload/pdf/van_der_Veer_SocialResearch-1097-1120.pdf.

Vicente, Victor A. (2007). "The Aesthetics of Motion in Musics for the Mevlana Celal ed-Din Rumi," Unpublished PhD thesis, University of Maryland.

Weidman, Amanda (2006). Singing the Classical, Voicing the Modern: The Postcolonial Politics of Music in South India, Durham, Duke University Press.

Werbner, Pnina (2003). Pilgrims of Love: The Anthropology of a Global Sufi Cult, London, Hurst.

\section{ENDNOTES}

1. The full name of this organisation that provides free public training is the Istanbul Metropolitan Municipality Art and Vocational Training Courses (İstanbul Büyükşehir Belediyesi Sanat ve Meslek Eğitimi Kursları [İSMEK]). Similar institutions also exist in other Turkish cities under different names. See: http://ismek.ibb.gov.tr/ism/index.asp.

2. "Ney Altın Dönemini Yaşıyor" [Ney in Its Golden Age], 5 April 2011. URL: http:// www.neyforum.biz/viewtopic.php?f=46\&t=535.

3. While the word maneviyat (an essentially Arabic word) is most commonly used for "spirituality" in the context of ney music learning, ruhaniyat (also essentially Arabic) and “ spiritüalite" are other expressions that figure in contemporary Turkish speech. Derived from French, the latter word is used in quarters such as psychology, counseling and healing practices. See Sevinç, Güven and Yeşilyurt's (2015) study on perceptions of religion and spirituality in Turkey.

4. See the interview titled "Ney, the 'absolute' instrument of the human soul," conducted with the ney player Melih Berse (Aydemir March 13, 2014); see also Dede (2003).

5. Breath is also a powerful source for many spiritual associations surrounding the ney. In most creation narratives the world is brought into being by breath: When I have shaped him and breathed My spirit into him ... (Hijr 15: 29). "Then the Lord God formed the man from the dust of the ground. He breathed the breath of life into the man's nostrils, and the man became a living person" (Genesis 2:7). The imagery of breath as a tool for creation, and the imagery of the body as an instrument of the soul is characteristic of Sufi metaphysics. For instance, the Mesnevi likens humanity to an instrument on which God plays: "[s]/he is the flute, which sings only when the divine breath first fills it" (Schimmel 1975: 166).

6. In terms of its structure, the Ottoman-Turkish ney contains six finger holes at the front and an additional thumb hole at the back. Sound is obtained by compressing air into the mouthpiece. The instrument has three main parts: the reed, başpare [mouthpiece] and parazvane (the metal rings placed in the upper and bottom ends of the reed to prevent cracking). Neys are made in various lengths according to their tuning. While the Kiz ney $(702-15 \mathrm{~mm})$ is most common among beginners today, the şah ney $(858-84 \mathrm{~mm})$ was most predominant up until the twentieth century. For technical features of ney types, see Ergüner (2002).

7. A note here on the choice of the words hoca and talebe instead of the much more widespread ögretmen [teacher] and ögrenci [student] is necessary. The enactment of language reforms (Dil Devrimi) in the high period of Kemalism (1920-1940s) in the name of nationalist "purification" involved for the most part the systematic expulsion of Arabic and Persian words from the new "Turkish" vocabulary. This was done through their replacement either by newly invented words or by words borrowed from Western European languages mainly including French, German and increasingly English (see Lewis 1999). It is in this context that the word hoca became ögretmen 
[teacher], and the talebe lost favour against the newly coined ögrrenci [student]. Although each pair of words seem to indicate similar subject positions - one who is charged with the act of teaching, and one whose duty is to learn - their shades of meaning reveal different kinds of sensibilities. The words öğretmen and öğrenci are unequivocally imbibed with a pragmatic functionality, made linguistically possible by the suffixes utilized to create them (-men and -ci respectively). Thus a "job-like" implication inheres in their use: one whose job is to teach, one whose task is to learn. As fieldwork revealed, it is not uncommon for those ney masters who had been disciplined within musical chains of transmission to instruct their pupils to avoid using the word ogrrenci and to opt for the word talebe instead. The Arabic roots of this word, tlb (to seek), connotes that learning is an orientation produced by the pupil. No matter how well one's hoca teaches, learning can only occur if the talebe demands knowledge.

8. The majority of my fellow-learners at the Hezarfen Ney School were adults, their ages ranging from 18 to their early sixties - this is in keeping with the general profile of most students taking up ney lessons today - and all active in the workforce (including medical doctors, IT specialists, lawyers, accountants, school teachers, and several small business owners), except for a few university students and one retired member. Women roughly made up one-third of the students. During the time I took lessons, there were over forty students coming to the workshop every week and approximately half of them had been learning from Salih Hoca for over five years.

9. More specifically, the sites of ney-learning where observation was undertaken for a six-month period include Istanbul State Conservatoire for Turkish Music, three İSMEK course centres (in Bostanc1, Fatih and Kağıthane), several private ney studios, and three cultural associations (dernek) located in the neighbourhoods of Eyüp and Fatih. While teaching at ISMEKs and associations almost always takes the form of collective lessons, a combination of individual and group lessons can be found in other places. Receiving tuition generally requires a monthly fee (varies from 50 to $200 \mathrm{TL}$ ) with the exception of İSMEKs where lessons are fully sponsored by local Istanbul municipalities. Observation activities extended also to music performances staged at Istanbul's numerous concert halls, regularly held sema performances at Galata and Yenikap1 Mevlevi Lodges, music workshops and "Islamic art seminars" organized by the Greater Istanbul Municipality. In addition to these activities, I conducted in-depth interviews with 22 ney masters (four were İSMEK ney instructors) and 20 students. The selection of interviewees represented the variety of pedagogical sites including the class background of the neighbourhoods they are located in, as well as the demographic characteristics of learners. Finally, the ethnographic analysis was complemented by media sources (e.g. ney forums, music magazines, album sleeves, published interviews with ney musicians, etc.).

10. Source: http://www.haberler.com/neyzenlerin-kamislarina-valilik-korumasi-haberi/.

11. Nicholson's translation, 1926. Source: http://www.dar-al-masnavi.org/reedsong.html.

12. The appropriation of the ney's spirituality is manifest in a large number of interviews conducted with ney musicians. As some of their titles reveal: "The Ney disciplines the Soul" (interview with Burcu Karadağ, 20 February 2004, Sabah, http://www.burcukaradag.com/ pressPhotos/7.jpg); "The Ney is the Sound an Ayin and the Symbol of the Perfect Human-being" (interview with Süleyman Ergüner, 12 January 2015, Dünya Bizim, http://www.dunyabizim.com/? aType=haberYazdir\&ArticleID=19216\&tip=haber); "The Sound of the Ney Expresses Separation and Longing” (interview with Betül Altınbaşak, 19 August 2012, Türkiye Gazetesi, http:// www.turkiyegazetesi.com.tr/yazarlar/betul-altinbasak/545884.aspx).

13. In fact, it is no coincidence that the most acclaimed proponents of Turkish-Sufi music today are all ney musicians such as Kudsi Ergüner, Mercan Dede and Omar Faruk Tekbilek, each of whom have incorporated the ney into their music in different ways.

14. Similar criticisms concerning the commodifying strategies of the world music industry that de-contextualize musical traits from their original context are ample in the ethnomusicological literature. Steven Feld's (1994) trope "schizophonia to schismogenesis" is useful here. According 
to Feld, once sounds are "split from their sources, that splitting is dynamically connected to escalating cycles of distorting mutuality, which in turn is linked to polarizing interpretations of meaning and value" (1994: 289).

15. Available at: http://www.side-underwatermuseum.com/gallery/.

16. Two major developments challenged the institution of lineage in the twentieth century: musical teaching at the Conservatoire following its establishment in 1975, and the emergence of the Turkish recording industry around the first quarter of the twentieth century, which allowed aspiring music practitioners to benefit from gramophone records as key learning supplements (see Poulos 2011). However the direct involvement of ney masters such as Niyazi Sayın, Süleyman Ergüner, and Salih Bilgin in the ney-teaching programme at the Conservatoire meant allowed new generations of ney talebes to become affiliated with long-existing lineages of neyzen masters, while taking up musical learning in the institutional setting of the Conservatoire. Salih Bilgin himself initially began working with Sayın in the early 1980s under the auspices of the Conservatoire, continuing thereafter at Sayın's Üsküdar house over the next fifteen years.

\section{ABSTRACTS}

Recently there has been a massive new interest in Turkey in the artistic practice of ney [reed flute]-playing. For some, much of the inspiration driving this interest connects to a search for the "spiritual." According to a popular discourse, there is no instrument more "natural" and "simple" than the ney. For others, inspired by the poetry of Rumi, the instrument's sound draws oneself closer to the Divine. While a close connection exists between this "spiritualization" of the ney and contemporary commercial developments in the global and Turkish music industry, the Turkish state too has been active in creating meanings about the "spiritual ney" by incorporating it into its tourism industry and nationalist ideology. By contrast, the critical reflections of the master musicians that my fieldwork study examines suggest a very different conception of spirituality. Here the "spiritual" experience of this musical practice is understood to be grounded not in the sounds of the instrument itself, but in learning the art in a certain way.

\section{INDEX}

Keywords: spirituality, ney, music education, Sufism, Turkey

\section{AUTHOR}

\section{BANU ŞENAY}

Macquarie University 